\title{
The Effect of the Teachers' Training Model "Academy- Class" on the Teacher Students' Professional Development from Students' Perspectives
}

\author{
Nabil Assadi \\ Pedagogical Instruction, Sakhnin Academic College for Teacher Education, Israel \\ Tareq Murad \\ Pedagogical Instruction, Sakhnin Academic College for Teacher Education, Israel
}

\begin{abstract}
AcademyClass, on teacher students' professional development according to their point of view. The research examines the influence of the new training model on the pre-service teachers' relations with their, training teachers, pedagogical instructors and the students of the school. The participants of the study were 32 third year students who study at Sakhnin College and do their training at nearby schools 'for three days. The instrument of the study was a questionnaire and an interview. The validity and reliability of the study instrument was obtained. The findings of the study were: 1 . The student teachers' level of knowledge, skills and qualifications of teaching and learning is higher after the program than before. 2. The teacher students experienced the training more effectively and efficiently after the program. 3. The student teachers are more convinced that they made more professional and correct choice of career after the program than before 4 . The student teachers' attitude towards the pedagogical instructor, the training teacher, the school students and the contribution of the training by the program towards strengthening the relationship with the school and its students was higher after the program than before.
\end{abstract}

Index Terms — academy-class, teacher's education, training teacher, pedagogical instructor, PDS

\section{REVIEW OF RELATED LITERATURE}

The colleges for teacher education in Israel consider the internship in teachers' education as the basis of their theoretical studies that take place inside them, and attribute a great importance to the preservice teachers' training (Khalil \& Asadi, 2005). According to Khalil and Asadi, one objective of the training programs is to give the student teachers the opportunity to practice their teaching at schools under the supervision of professional and veteran training teachers from schools, and expert pedagogical instructors from the academy.

Inside the schools, the student teachers are exposed to various factors that are involved in the teaching and school management. They also observe activities that occur training schools and try to discuss and analyze them. In addition, student teachers observe lessons, prepare lesson plans, teach and evaluate their lessons (Khalil \& Asadi, 2005).

During the practical work at schools, these students will know the education system- teaching facilities, curricula and different populations of school students. They also know textbooks and didactic aids used in teaching different subjects and disciplines, and will experience different teaching methods. Following practical training, student teachers will acquire work habits, learn to prepare balanced and efficient lesson plans and equip themselves with tools to prepare a teaching unit and develop it.

Academic colleges for teacher education combine between different models of training: traditional training, PDS and academy-class, the last one is experimental. According to the first model, which is frequently used in teachers' education in Israel, the student teachers are sent to training schools and are accompanied by training teachers from the school for observation and experiencing lessons in the subject matters that the students study at the academy. One drawback of this model is that the students from the college feel lonely because of the disconnection between the theories they study at the college and practice they experience at schools

Since eighties, reforms in teacher education took place in England and the United States. These reforms affected other countries of the world in general and Israel in specific. The essence of these reforms is the partnership between the field-the training schools- and the academy where these students study, thus the academy institutes serve as a source of theoretical, disciplinary, and didactic knowledge for the schools, on the other hand, schools serve as a practical field for the student teachers from the academy. Based on these concepts, experts from Israeli ministry of education began to 
develop different models for teacher training, including the American model: "Professional Development Schools (PDS).

While school-university partnerships are a relatively new concept, the community schools ideology dates back over 100 years. It reemerged in the early 1980s in response to concerns about the serious challenges, such as violence, drugs and poverty, facing inner-city school students (Hunzicker,J., Schifeling,J., Sattler, L. \& Lathan,J, 2012).

Goodlad (1990) states that in PDS model, the academy sends a group of students to a training school together with a pedagogical supervisor from the academy. The school provides a field for practical work and the academy provides the theory, and both the school and the academy work in partnership. Within this PDS framework, the academy members conduct professional development activities for mentor teachers and provide supervision of student teachers. The collaborative nature of the PDS environment allows for continuous evaluation and the growth of pre-service teachers. In this model, the student teachers do not only learn from the individual training teacher, but also from the system, that has organizational and pedagogical restrictions.

The experts develop this Model in teachers' training institutes to "expand" the training process of the student teachers (Ariav, 2001; Zelberstein, 1995). In addition to the support and guidance from a training teacher, the preservice students are exposed to authentic situations of teaching and learning or other tasks from the life of the school. A group of students takes part in the various activities that held at the school, these activities related to the school system during the study day, or activities after the school day. The experience that the student teachers tackle during the day at the training schools is of mutual benefit, both for the students and the educating schools.

PDS models appeared in Holmes Group Report, Tomorrow teachers, in 1986 for the first time. Although this model combines, elements such as development center (Clark, 1990) and collaborative school (Goodlad, 1990), this model is more than a school lab or a place for clinical development of novice teachers, but it is considered to be new institution (Holmes Group, 1986). Unlike the traditional model, PDS creates partnership between the training school and the Academy where the preservice teachers study (Ariav, 2001; Zelberstein, 1995). This training program gives students the opportunity to experience teaching during the real life at school (Kizel, 2010). In addition, it could help failing schools improve themselves and make positive changes through partnership with the academy (Hill, L., Mellon, L., Goddard, J. \& Laker, B., 2016).

Ariav (2001) and Cochran-Smith (1990) define the partnership as an opportunity for simultaneous development of preservice teachers, their teachers in the academy and teacher staff of the training school. Cochran-Smith (1990) draws three models for the potential partnership: agreement model, mismatch and cooperative coordination model.

Although many research on PDS model were conducted in the recent years, no fully developed instructions for the project appeared. The creators of the program emphasize that their efforts requires not only time to have its merits in teacher training, but also hard work in order to arrive the required level to function according to the plans. PDS model is similar to that of training doctors of medicine in the hospitals (Goodlad, 1990; Holmes Group, 1986; Kenndy, 1990).

In PDS model, not only training teachers are involved in training student teachers but also the entire school takes part in educating these teachers (Goodlad, 1990; Clark, 1990). The student's diversity: ethnic, financial and geographical should be taken into account while training in PDS program (Pasch, pugash \& Marleen, 1990).

On the other hand, PDS model in teachers' training has some drawbacks such as consuming many resources (Zimpher, 1990), and they lack suitable programs that regulate partnership between teachers' education institutes and the training schools which receive the pre service teachers. Another weakness for PDS model is that it is very difficult to find a training school that can receive student teachers; therefore, the students should prepare themselves for competition on a place to practice (Zimpher, 1990). Therefore, there is a need for another attractive training program for schools and training teachers.

The most current model in teacher education in Israel is 'academy-class'; it was carried out during the year of 2015/16 in teachers' education in Israeli universities and colleges. It is a pilot and experimental program. This program is based on the principles of PDS that consider partnership between training schools and the academy as essential step in teachers' education (Greany \& Brown, 2015). There is a growing perception of the need for partnerships to promote learning at all levels, whether they are formally constituted as looser affiliations like those identified by Lieberman (2000). Such a perception derives from the recognition that the collaboration between stakeholders potentially optimizes learning. The recommendations in the Ramsey review (2000) further promoted discussion of the desirability of partnerships.

Brady (2002) stated that there is a strong support for a great variety of partnership initiatives between schools and universities in the promotion of student teacher learning, school student learning, and the professional development of lecturers and teachers.

Academy class relies on the partnership between university and schools. The literature on school-university partnerships highlights the challenges involved in making such partnerships successful. Differences in language, culture and organizational priorities can be compound by logistical difficulties, meaning that it can be hard to demonstrate impact (Greany \& Brown, 2015).

Greany and Brown (2015) claimed that learning from successful partnerships voice with practitioner priorities and knowledge explicitly valued. The creation of a 'third space' allows more creative ways of working; strategic leaders who recognize and prioritize external working of this nature as well as distributed and shared leadership across the 
boundaries between the partners; and shared aims and approaches, for example through a focus on solving locally defined problems utilizing an enquiry approach.

Ingersoll, May and Merill (2014) found that pedagogical content in teachers' education has an effect on teachers' endurance in teaching; teachers who studied pedagogy, teaching instructions and did observations and reflections in their training, were less likely to leave teaching at schools.

Academy- Class is a new program in teachers' education suggested by the Ministry of Education in Israel. Its ultimate objective is to change teachers' training based on partnerships and collaborations between academy institutes and leading schools. This is to improve the qualities of training processes, teaching and professional development of, developing meaningful learning in education institute and expanding partnership between universities and schools (Ministry of Education, 2014), this instruction proposes a broad collaboration between schools and universities and colleges for teacher training based on PDS model which has been implemented in Israel for decades.

The essence of the program is that the teachers' education institutes send the third year student teachers to leading schools for three days during the week, 12-15 hours per week. The pre-service teachers co-teach with experienced teacher from the school, the responsibility to promote the training of the pre-service teachers' education lies on all factors that are involved in teacher' education such as: schools, training teachers and pedagogical supervisors.

In the school student teachers practice co-teaching together with experienced and qualified training teachers from the school. The training or coaching teachers receive adequate financial compensation for supervision and mentoring students. A pedagogical supervisor who has the theories from the academy institute will accompany the students. In addition, the academy provides courses for the school teachers' professional development (Ministry of Education, 2014).

In this research, the researchers investigate the effect of the new and experimental program in teacher education, Academy-Class, on the preservice student's professional development from the students' perspective.

\section{METHODOLOGY}

\section{Subjects}

The participants of the current study are 32 students from The College of Sakhnin for Teacher Education in the Northern District of Israel. The Students are third year students that study English and Mathematics. The college chooses these students to participate in a pilot model for teacher training called academy-class. The teacher students went to practice their teaching in three junior and four elementary school in the area; the students went to the training schools three times a week.

Instrument

The researchers used the following instruments to achieve the purpose of the study:

The researchers developed a questionnaire and interview. A group of experts in teachers' education, in the college, validated these tools. They researchers also made reliability for the instruments after being tested on a pilot group. The participants filled the questionnaire and were interviewed before and after participating in the program.

\section{RESEARCH FINDINGS}

The aim of this research is to examine the contribution of the program 'Academy-Class' from the perspective of the students with regard to their professional development, as demonstrated in terms of the following factors:

knowledge, skills of learning and teaching instructions, the contribution of the training teachers and the pedagogical supervisors, the relationship with training schools, and the intention of the students to continue in teaching.

To answer the research question, t-tests for designs that depend on the knowledge variable, skills and the capability of learning and teaching of the students, students' attitudes towards the efficiency of the program, and feelings about the choice of the teaching profession (decision). In addition, descriptive statistics examined the attitude of the students about the contribution of the training teacher and the pedagogical supervisors to the practicum of the students. The research also examines the contribution of the program to the student teachers' relationship with the school and its students. Table One shows.

TABLE 1

THE RESUlTS OF T-TEST

\begin{tabular}{llll}
\hline \multicolumn{4}{c}{ THE RESULTS OF T-TEST } \\
\hline Variable & Before (N=32) M (SD) & After $(\mathrm{N}=32) \mathrm{M}(\mathrm{SD})$ & $\mathrm{t}(31)$ \\
\hline Capability & $3.81(0.75)$ & $4.18(0.54)$ & $2.68^{* *}$ \\
Efficiency of the program & $4.01(0.85)$ & $4.42(0.63)$ & $2.11^{*}$ \\
Decision & $4.13(1.13)$ & $4.67(0.55)$ & $2.28^{*}$
\end{tabular}

The findings of the table show that the student teachers' level of knowledge, skills and qualifications of teaching and learning of the students a higher after the program $(M=4.18 \mathrm{sd}=0.54)$ than before it $(\mathrm{M}=3.81$, $\mathrm{sd}=0.75)$. This shows that the academy- Kitta program has a significant effect on the students level of knowledge, skills and qualifications [ $\mathrm{t}_{(31)}$ $=2.68, \mathrm{p}<0.01]$.

In addition, the students experienced the training more effectively and efficiently after the program $(\mathrm{M}=4.42, \mathrm{sd}=0.63)$ than before $(M=4.01, \mathrm{sd}=0.85)$. This shows that the program has a significant effect on the students' experience of 
teaching $\left(\mathrm{t}_{(31)}=2.11, \mathrm{p}<0.05\right)$. Finally the student teachers are more convinced that they made more professional and correct choice after the program $(\mathrm{M}=4.67, \mathrm{sd}=0.55)$ than before it $(\mathrm{M}=4.13, \mathrm{sd}=1.13)$ significantly $\left(\mathrm{t}_{(31)}=2.28, \mathrm{p}<0.05\right)$.

The following table shows descriptive statistics of the student teachers' attitude towards the pedagogical supervisor, the training teacher and the contribution of the practicum by the program towards strengthening the relationship with the school and its students.

TABLE 2

THE STUdENT TEACHERs' ATTITUdes TOWARdS THE CONTRIBUTION OF THE PEDAGOGICAL SuPERVISORS,

\begin{tabular}{ll}
\multicolumn{2}{c}{ TRAINING TEACHER, THE RELATIONSHIP WITH SCHOOL AND ITS STUDENTS } \\
\hline Variable & M (SD) \\
\hline The contribution of the pedagogical counselor & $4.38(0.73)$ \\
The contribution of the teacher trainer & $4.19(0.91)$ \\
Relationship with School & $4.54(0.58)$ \\
Relationship with students & $4.66(0.60)$ \\
\hline
\end{tabular}

This Table shows that variables range between 1-5, therefore, the findings indicate that the students indicate that the contribution of pedagogical supervisor is high $(\mathrm{M}=4.38, \mathrm{sd}=0.73)$. So is the contribution of the training teacher $(\mathrm{M}=4.19$, $\mathrm{sd}=0.91$ ). The participants also felt that the program contribution towards their relationship with school is high $(\mathrm{M}=4.54), \mathrm{sd}=0.58)$. so is the relationship with the school students $(\mathrm{M}=4.66, \mathrm{sd}=0.60)$.

\section{Qualitative Analysis for the Student Teachers' Reactions}

In addition to the quantitative questions, the researchers asked the participants open questions before and after the program. These questions undergo qualitative analysis, the researchers found a number of central themes at each step.

The objectives of the program

Before the implementing the program, the student teachers were asked what are the main objectives of the program, academy-class, for preservice teachers?

The researchers divided the participants' answers into three central themes:

1. Increasing self confidence

This is the main theme and the most common among student teachers, one participant reported that before the program, the students were busy in in increasing the self- confidence. Another said that one objective of the program is reducing the feelings of fear of the classroom.

2. Experience and Tools

The student teachers were also engaged in acquiring teaching skills, and hope that the program could provide them with these tools. One student talked about experience and instruments that improve the ability of teaching, another hoped to receive practical tools.

3. Strengthening the feeling of belonging to the school

This theme was also common. It was about the relationship between the student teachers and the training school and its students. One of participants stated that the objective is to strengthen the relation with the school system. Another talked about the feeling of being a part to the training school.

After participating in the program, the researchers ask the subjects, what is, in your opinion, the objective of the program, academy-class for preservice teachers?

After the program, the main themes were different from those before it

1. Experience and Tools

This was main and the central theme after the program. The students were more engaged in the tools and the experience that they acquire during the program. One participant said that the program strengthen the pedagogical knowledge, another, said that after the program, she learnt new teaching methods, and she knew more about teaching after participating in the program.

2. Increasing self confidence

After the program, this theme relatively was not the main. This was the main theme before the program, few participants relate to this topic. One subject said that she got a self- confidence to face the classroom... Another claimed that it provided confidence against the school students...

Before the program, the student teachers lacked the confidence, and focussed on their ability to stand against the school students. After the program, their confidence improved, and they were engaged in improving their teaching methods.

Other Factors that Affect Teachers' Training and Education

Another question that the researchers asked the participants before and after implementing the program was: apart from the pedagogical supervisors and the training teacher, what other factors could affect their training in the field and their qualification for teaching?

There were differences in the subjects' answer before and after the program. Before the program, the main and the central theme of the students was, colleagues and teachers from the school in different variations for example, one participant said: "the school teachers could help and contribute in different solving problems". Another claimed that training teachers can contribute to their training. On the contrary, after the program, the student teachers spoke about the school students that they taught, as a main theme in the successes of their training. One student teacher said: "the 
interaction with the school students has a great influence on their training". Another talked about the influence of relationship that the pre-service teachers make with the school students.

It is known that before the program, the participants hoped for a help from other teachers in the teachers' room, however, after the programs the student teachers understood that the teachers are engaged with their students and classes and they have a little time to sit the trainee.

Another theme that was not significant, and without difference before and after the program was the relationship with the school principal. It seems that in some schools, the principal felt obliged for the process and was more involved in the program. One participant stated: "the principal had a main function in the program, "Academy-class, because he gave us support". Another said: "the principal was very involved in the program".

The success of the program

Finally, the researchers asked the participants what, in their opinions, could be considered a success for the program?

The researchers classified the subject's answers before the program for the following themes:

1. Self Confidence

This theme emerged before the program, because the participants seemed that they had a need for increasing their confidence. One said: "a support from any factor could help strengthening our confidence". Other hopes for a support from the system.

2. Improving the school students' skills

Some participants considered the success of the program as a success in improving the school students' behavior, performance and achievement, for example, one participant said that the program developed the students' performance and improved their achievements. Other said: I can improve the school students".

After the program, the participants' answers were classified to the following themes:

1. The implementation of the theory from the academy to the field

Many participants commented that the success of the program depends on the implementation of what the students study in the academy in the schools against the school students during their practical training. One student said: "the student teacher should apply the theories from the college in the school". Another talked about the possibility to use the strategies, methods and tools they acquired in the college in their practicum.

2. Improving the school students' performance

After the program, the participants considered improving the school students' performance as a criterion for the success of the program, for example, one subject said that the program should develop the students' achievements. Another noted that it should improve the school students' thinking and knowledge.

The impression is that the participants changed their opinions after the criteria of success after the program. Before the program the student teachers were engaged in their confidence as teachers in the future, after the program they were engaged in implementing the teaching methods and instruction in their practicum at schools, they were also busy in improving their image as teachers. TH criterion of improving the school students' achievement was a central theme before and after the program.

Questions that asked before

The researchers asked the participants about the contribution of the presence of the pedagogical supervisor during the training. This question consists of four subcategories: contribution to the students, contribution to the training teacher, contribution to the school and its students.

The contribution of the supervisor from the college to the student teachers

In this "sub-category, the participants wrote about the availability of the supervisors, for example one student wrote: "the presence of the pedagogical guides at school is essential, so I can meet them immediately when needed. Another said that she did not need to wait for the guide, because he is available at school all the training day. Another talked about the guide as a source of information. The participants considered the guides availability during the practicum day as a possibility for professional development. In addition, the participants commented about the confidence that they got from the guides for example, one said: "the presence of the pedagogical guide increases the feeling of confidence".

The contribution of the pedagogical guide to the training teacher

The participants also highlighted the importance of the presence of the guides, and claimed that the guides contribute to the training teachers. They can help the trainers by providing theories from the academic literature, and then the trainee can benefit from these theories. One participant stated: "the training teacher together with the supervisor are partners for reflection, evaluation and feedback". Another said that the students could benefit from the guide's experience either in teaching methods or classroom management.

The pedagogical guide' contribution to the school students

The researchers divided the participants' answers to two themes. One related to an indirect contribution of the pedagogical supervisor. They help the trainees and the trainers to help the school students. One student said that the comments and the reflections that they got from the supervisors help them deal with the school students more efficiently. The second theme is the availability of other factors in the school, so the school students got more attention especially when there are two teachers, veteran and novice that do co teaching in the same class.

The contribution of the pedagogical supervisor to the school. 
The participants believed that the attendance of the supervisors to the school had a significant effect by making order and reducing the students' and the school staff pressure. He also intermediates between the school and the student teachers. In addition, the researchers asked the students about the effect and the contribution of the training teacher in the class where they experience their teaching. The researchers divide the question into four sub items: the contribution for the students, the contribution to the pedagogical supervisor, the contribution to the school and its students.

The contribution of the training teacher to the student teachers

The participants indicted that the training teacher helped them in their study and professional development. Some student wrote, "She taught us new teaching methods and instructions. Other claimed that the training teacher taught her new strategies in teaching.

The contribution of the training teacher to the pedagogical supervisor

The students indicated the importance of the teamwork between the training teacher and the pedagogical supervisor. Some said " one staff, one completes the other", another wrote: "full cooperation in guidance and activities". The students considered the partnership and cooperation between the trainer and the supervisor as a main contributor to their training and professional development.

The contribution of the training teacher to the school students

The student teachers highlighted the contribution of the experienced teacher to the school students' improvement. They indicated that their presence at the school with the students enhanced their skill of improving the school students' performance, for example, "to improve them individually and socially", another said that the training teacher knew what and how to teach the school students.

The contribution of the training teacher to the school

The students considered the training teacher as an essential staff member, who has the ability to contribute and improve the school system. One participant said: "she could contribute to improving school system by increasing the educational level, another said: "she improves the school students' level".

\section{Discussions AND CONCLUSIONS}

The purpose of the study is to investigate the effect of the academy- class (a teacher education model) on the preservice students' professional development. Concerning the following factors: knowledge, skills and teaching methods of the students, the contribution of the pedagogical supervisor from the academy and the training teacher from the school, the relationship with the school and its students and the student teachers plans for their work in teaching.

Data analysis shows that the participants benefited a lot from their training with the new model academy-class. The answers to the questionnaire, which examined the student teachers' feeling toward the level of their knowledge, skills and qualifications showed a significant effect of the new training model at the end of the training process.

The participants also reported that academy-class, the new training model, contributed to their teaching experience, skills and methods. The model succeeded to improve their abilities to teach students inside the classrooms. In addition, the students reported that the pedagogical supervisor had a significant effect on their success after the training; the preservice teachers also indicated the contribution of the training teacher on their training and their professional development.

Additional contribution for this new model is strengthening the relationship between the trainee and the students of the school. Moreover, the participants reported that Academy-Class, a new model for teacher training in Israel, helped them in their decision to choose their field of study, and their decision to either continue or stop teaching, in other words, after the training the trainees felt more confident, so they have more time to deal with teaching methods and instructions than before.

\section{REFERENCES}

[1] Ariav, T. (2001). Teacher Education and Schools. A Different System of relation: Reactions and Opinions. A Discussion Paper No 6. Mofet Institute. TA. In Hebrew.

[2] Brady, L. (2002). School University Partnerships: What Do the Schools Want? Australian Journal of Teacher Education, 27 (1), $1-8$

[3] Clark, Richard W. (1990). What School Leaders Can Do to Help Education? Washington DC, American Association of Colleges for Teacher Education.

[4] Cochran-Smith, M. (1990). Reinventing Students Teaching. Journal of Teacher Education, 42, (2), 104-119

[5] Goodlad, J. (1990). Teachers for our nation's schools. San Francisco: Jossey-Bass.

[6] Greany, T., \& Brown, C. (2015). Partnerships between Teaching Schools and Universities: Research Report. UCL Institute of education.

[7] Hill, A., Mellon, L., Goddard, J., \& Laker, B. (2016). How to Turn Around a Failing School. Retrieved, September, 2016 From, https://hbr.org/2016/08/how-to-turn-around-a-failing-school.

[8] Holmes Group, (1986). Tomorrow Schools: Principles for the Design of Professional Developments Schools. East Lansing, MI: Author. SP 032871

[9] Hunzicker, J. Schifeling, J. Sattler, L. \& Lathan, J. (2012). School-University Partnerships: A Model for Education Reform in Peoria. Retrieved, 2016, from: http://www.peoriamagazines.com/ibi/2012/aug/school-university-partnerships-model-educationreform-peoria. 
[10] Ingersoll, R., May, H., \& Merill, L. (2014). what are the effects of teacher's education and preparation on beginning teachers' attrition. Research Report. Pennsylvania. Consortium for policy research in education.

[11] Khalil, M., \& Asadi, J. (2005). The Guide for Practicum in Teachers' Education. The College of Sakhnin for Teacher Education. In Arabic

[12] Kenndy, M. (1990). Professional Schools. NCRTE Colloquy. 3 (2). SP032 752.

[13] Kizel, A. (2010). School for professional development in Teacher Education. Retrieved, August, 2016 from, http://akizel.blogspot.com/2010/08/pds.html.

[14] Lieberman, A. (2000). 'Networks as learning communities: Shaping the future of teacher education'. Journal of Teacher Education, 51 (3) 221-7.

[15] Ministry of education, (2014). Academy-Class. Jerusalem. Ministry of Education.

[16] Pasch, Suzanne H., Pugach, \& Marleen C. (1990). Collaborative Planning for Urban Professional Development Schools. Contemporary Education, 61 (3), 135-143.

[17] Ramsey, G. (2000). Quality Matters: Revitalizing Teaching: Critical Times, Critical Choices. Report of the Review of Teacher Education. Place: Publisher.

[18] Zelberstein, M. (1995). Teaching as Practical and Reflective Work: Implications for Training Teachers. A Paper Submitted to the Chairman of the Standing Committee at the Pedagogical Secretariat. Jerusalem: Ministry of Education. In Hebrew.

[19] Zimpher, N. L. (1990). Creating Professional development schools sites. Theory into Practice, 29 (1).42-49.

Nabil Assadi was entitled his Bachelor of Arts degree from Haifa University in 2002 in Statistics. He received his Master of Arts in Education Teaching Specialization in Teaching Mathematics in 2006.

He has been teaching mathematics in High Schools since 2003. He has also been teaching math instruction in the Sakhnin Academic College for Teachers' Education and he is a Pedagogical Instructor since 2010. His research interest is in Pre Service Teachers' Education. He is a candidate for a Ph.D. with a research proposal on ICT for Pre-Service Math Teachers.

Tareq Murad PHD in English linguistics and instructions. He has been teaching linguistics courses: syntax, semantics and discourse analysis for 15 years. He recently is the general coordinator of the pedagogical instruction at the Academic College of Sakhnin for Teacher Education. He conducted several researches on cross cultural pragmatics and supervision instruction. 